International Journal of Social Science And Human Research

ISSN(print): 2644-0679, ISSN(online): 2644-0695

Volume 05 Issue 01 January 2022

DOI: 10.47191/ijsshr/v5-i1-25, Impact factor-5.586

Page No: $167-178$

\title{
The January 6, 2021 Riot, the USA FREEDOM Act of 2015, Thomas Hobbes, John Locke, and Controlling the Content of Extremist Material on the Internet
}

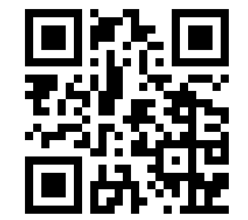

\author{
Donald L. Buresh, Ph.D., J.D., LL.M. \\ Morgan State University
}

\begin{abstract}
The purpose of this essay is to discuss the January 6, 2021 riot and its relationship to the USA FREEDOM Act and to how Thomas Hobbes and John Locke would react to the content of extremist material on the Internet. The paper argues that the January 6, 2021 riot could be construed as an example of extremist behavior that may be regulated on the federal level. The possible opinions of Thomas Hobbes and John Locke are analyzed, demonstrating that in society, there is a wide range of opinions regarding how extremisms should be addressed. The answers are not clear-cut but require fine-tuning as high emotions dissipate and calmer minds prevail.
\end{abstract}

KEYWORDS: Extremist Material, January 6, 2021 Riot, John Locke, Thomas Hobbes, USA FREEDOM Act of 2015

Abbreviations:

The following abbreviations are used in this manuscript:

\begin{tabular}{|l|l|}
\hline Abbreviation & Description \\
\hline DNI & Director of National Intelligence \\
\hline FISA & Foreign Intelligence Surveillance Act \\
\hline USA FREEDOM Act & $\begin{array}{l}\text { Uniting and Strengthening America by Fulfilling Rights and Ending Eavesdropping, } \\
\text { Dragnet-collection, and Online Monitoring Act }\end{array}$ \\
\hline USA PATRIOT Act & $\begin{array}{l}\text { Uniting and Strengthening America by Providing Appropriate Tools Required to } \\
\text { Intercept and Obstruct Terrorism Act }\end{array}$ \\
\hline
\end{tabular}

\section{INTRODUCTION}

On January 6, 2021, a crowd invaded the halls of Congress as people were climbing the outside walls of the building and rushing the doors. The mob entered the building, intent on confronting the members of Congress that Joseph Biden and the Democratic Party stole the November 3, 2020 election from Donald Trump and the Republican Party. ${ }^{2}$ For a while, chaos reigned in the building. A Capital police officer fatally shot Ashli Babbitt while a stampede of fellow rioters crushed Rosanne Boyland. Kevin D. Greeson died of a heart attack, and Benjamin Philips died of a stroke. Capital Officer Brian D. Sicknick, an individual who was attacked by the mob, died the next day. Officer Jeffrey Smith of the Metropolitan Police and Officer Howard S. Liebengood of the Capital Police committed suicide, allegedly because of the riot. ${ }^{3}$

\footnotetext{
${ }^{1}$ Erin Doherty, \& Oriana Gonzalez, In photos: An hour-by-hour record of the Jan. 6 Capitol riot, Axios (Jan. 6, 2022), available at https://www.axios.com/capitol-riot-january-6-anniversary-c61435e4-f4c4-4f5a-b6d1-9c463ac7eed2.html.

${ }^{2}$ See generally, Thomas Dreisbach, Meg Anderson, \& Barbara van Woerkom, 5 Takeaways from the Capitol Riot Criminal Cases, One Year Later, NATIONAL PUBLIC RADIO (Jan. 5, 2022), available at https://www.npr.org/2022/01/05/1070199411/5takeaways-from-the-capitol-riot-criminal-cases-one-year-later.

${ }^{3}$ Chris Cameron, These Are the People Who Died in Connection With the Capitol Riot, THE New YORK TIMES (Jan. 5, 2022), available at https://www.nytimes.com/2022/01/05/us/politics/jan-6-capitol-deaths.html.
} 


\section{The January 6, 2021 Riot, the USA FREEDOM Act of 2015, Thomas Hobbes, John Locke, and Controlling the Content of Extremist Material on the Internet}

The reaction to the event has been mixed. Many Democratic members of Congress have declared that the events that took place on January 6, 2021, were an insurrection. ${ }^{4}$ However, of the individuals who have been charged and convicted of their illegal actions on that fateful day, as of January 6, 2022, no one has been charged or convicted of insurrection one year later. ${ }^{6}$ More than 725 people have been arrested in connection with the Capitol riot. At least 165 have pleaded guilty (145 to misdemeanors and 20 to felonies). About 70 individuals were sentenced, 30 people received prison time, and 40 were given probation. The charges ranged from misdemeanors for parading or picketing inside the Capital building to felonies such as assaulting a police officer with a deadly weapon. ${ }^{7}$ More conservative pundits have proclaimed that what happened on January 6, 2021, was not an insurrection at all but a riot. $^{8}{ }^{9}$ Jenkins observed that the word "insurrection" is inappropriate because there was no attempt to overthrow the federal government and form a new government. ${ }^{10}$

The events that occurred on January 6, 2021, will likely be hotly debated in the years to come. For years, the event's causes will probably be analyzed and digested ad nauseum. What is clear is that the participants of the January 6, 2021 mob were passionate about what they believed and the outcome they wanted - Donald Trump being reelected as President of the United States. Whether they were violent extremists that were hell-bent on achieving their goals or frustrated voters expressing their discontent with the November 3, 2020 election outcome is an open question. What is true is that whatever the answer is, the government must address the event in a way where justice, fairness, transparency, and the rule of law win in the end, and violent extremism loses.

\section{USA FREEDOM Act of 2015}

The USA FREEDOM Act (Pub. L. 114-23) is a United States law that was enacted on June 2, 2015. The Act either restored or modified provisions of the USA PATRIOT Act. ${ }^{11}$ Initially, the title of the Act is a backronym for Uniting and Strengthening

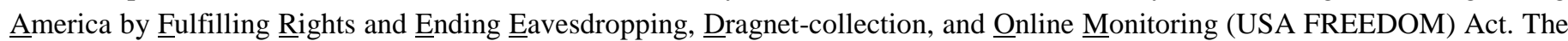
Act enacted a ban on Section 215 bulk data collection activities. It also mandated that the Foreign Intelligence Surveillance Act (FISA) court publish so-called "novel" interpretations of the law. ${ }^{12}$ The Act does not explicitly specify whether it demands retroactive discloses of decisions before the Act was passed in 2105.

The USA FREEDOM Act consists of eight titles, including: ${ }^{13}$

- Title I: FISA Business Records;

- Title II: FISA Pen Register and Trap and Trace Device Reform;

- Title III: FISA Acquisitions Targeting Persons Outside the United States Reforms

- Title IV: Foreign Intelligence Surveillance Court Reforms;

- Title V: National Security Letter Reform;

- Title VI: FISA Transparency and Reporting Requirement;

- Title VII: Enhanced National Security Provisions; and

- Title VIII: Safety of Maritime Navigation and Nuclear Terrorism Conventions Implementation.

Title I bans bulk data collection under Section 215 of the USA PATRIOT Act. ${ }^{14}$ It requires that the government specifically identify an individual, account, address, or personal device as reasonably practical. The government has reasonable suspicion that the item

\footnotetext{
${ }^{4}$ Jonathan Tamari, \& Julia Terruso, 'A clear and Present Danger.' Pa., N.J. Democrats Say Threats Remain a Year After the Jan. 6 Insurrection, PHILADELPHIA INQUIRER (Jan. 6, 2022), available at https://www.inquirer.com/news/pa-jan-6-anniversary-caseywild-kim-20220106.html.

${ }^{5}$ Charlie Savage, Was the Jan. 6 Attack on the Capitol an Act of 'Terrorism'?, THE New YORK TIMES (Jan. 7, 2022), available at https://www.nytimes.com/2022/01/07/us/politics/jan-6-terrorism-explainer.html.

${ }^{6}$ Ryan Lucas, Where the Jan. 6 insurrection investigation stands, one year later, NATIONAL PUBLIC RADIO (Jan. 6, 2022), available at https://www.npr.org/2022/01/06/1070736018/jan-6-anniversary-investigation-cases-defendants-justice.

${ }^{7}$ Id.

${ }^{8}$ Holman W. Jenkins, Jr., Why the Jan. 6 'Big Lie’ Narrative Will Fail, THE WALL StreET Journal (Jan. 7, 2022), available at https://www.wsj.com/articles/the-big-lie-narrative-will-fail-mainstream-media-jan-6-journalism-2020-election-capitol-riotprotest-trump-11641574341.

9 The Editorial Board, Democracy Isn't Dying, THE WALl STREET Journal (Jan. 5, 2022), available at

https://www.wsj.com/articles/democracy-isnt-dying-capitol-riot-jan-6-donald-trump-election-11641421265.

${ }^{10}$ Holman W. Jenkins, Jr., supra, note 8.

${ }^{11}$ Jody C. Liu, So what does the USA Freedom Act do anyway?, LAWFARE, (June 03, 2015), available at

https://www.lawfareblog.com/so-what-does-usa-freedom-act-do-anyway,

${ }^{12}$ Benjamin Wittes, \& Jodie Liu, So What's in the New USA Freedom Act, Anyway?, LAWFARE (May 14, 20915), available at https://www.lawfareblog.com/so-whats-new-usa-freedom-act-anyway.

${ }^{13}$ USA Freedom Act of 2015 (Pub. L. 114-23), available at https://www.govinfo.gov/content/pkg/PLAW-114publ23/html/PLAW114publ23.htm.

${ }^{14}$ Jody C. Liu, supra, note 11. 


\section{The January 6, 2021 Riot, the USA FREEDOM Act of 2015, Thomas Hobbes, John Locke, and Controlling the Content of Extremist Material on the Internet}

is affiliated with a foreign state. All collateral data collected must be destroyed. Title II concerns pen registers and trap and trace devices. ${ }^{15}$ Like Title I, Title II bans bulk data collection except if the item to be collected is accurately described. Titles III addresses data collection issues under Section 702 of the USA PATRIOT Act. ${ }^{16}$ Title III excludes any data collected under Section 702 via procedures thought to be deficient by a FISA court regarding a United States citizen. The government may neither use nor disclose such information.

Title IV reforms the FISA court. It allows amici curiae to be appointed by the FISA court when there is a novel or significant interpretation of the law. ${ }^{17}$ It also provides for a limited appellate review, and it requires the Director of National Intelligence (DNI) to implement a declassification review of FISA court opinions involving a significant construction or interpretation of the law. Title $\mathrm{V}$ modifies the National Security Letter program by extending the ban on bulk data collection except if the application is predicated on a specific selection term.

Title VI specifies extensive disclosure requirements regarding FISA data collection. ${ }^{18}$ The government must disclose to Congress, and the public statistics about the number of orders and certifications sought and received, an estimate of the number of individuals targeted and affected by surveillance, the number of amici curiae appointments, etc. Title VII concerns the targeting of non-United States citizens. Title VII establishes an emergency exception that permits the government to target so-called "roamers," or individuals who are not United States citizens but suddenly show up inside America. Furthermore, according to Liu, the title expands the definition of an "agent of a foreign power" to include non-U.S. people who: ${ }^{19}$

- Are lawful targets under conventional FISA warrants, but are improper objectives after they leave the United States;

- Engage in proliferating weapons of mass destruction or preparation of activities thereof; or

- Knowingly aid or abet or knowingly conspire with a third party in activities connected with the global proliferation of mass destruction.

Finally, Title VIII is concerned with the international obligations of the United States regarding maritime safety and nuclear terrorism. ${ }^{20}$

\section{The Philosophers Thomas Hobbes and John Locke}

This section aims to review the philosophies of Thomas Hobbes and John Locke. Each philosopher's writings will be discussed in turn.

\section{Summary of Hobbes' Philosophy}

As a supporter of Charles I, King of England, Scotland, and Ireland, Hobbes believed in an absolute monarchy, or in modern terms, a dictator where the decisions of government rested in one individual. ${ }^{21}$ Hobbes believed in a social contract where the rights of the people are subject to the will of the ruler. ${ }^{22} \mathrm{He}$ thought that when individuals were left to their own devices, they gave little consideration to their fellow human beings. In other words, people are selfish rather than altruistic. ${ }^{23}$ Hobbes felt that control by a monarch or a dictator is inescapable to ensure order within society. ${ }^{24}$ The philosopher demanded that the people obey the government to uphold law and order. ${ }^{25}$ Finally, Hobbes posited that citizens should be obedient servants to a monarch or dictator, even if the government is cruel or violent. ${ }^{26}$

\section{Summary of Locke's Philosophy}

In contrast, Locke did not believe in absolute monarchies. This is not surprising given that the Two Treatises of Government were published in 1690 at the beginning of the reign of William of Orange and his wife Mary, and after the Glorious Revolution of 1688, where James II was deposed. ${ }^{27}$ Fundamentally, Locke believed in parliamentary government, where the members of

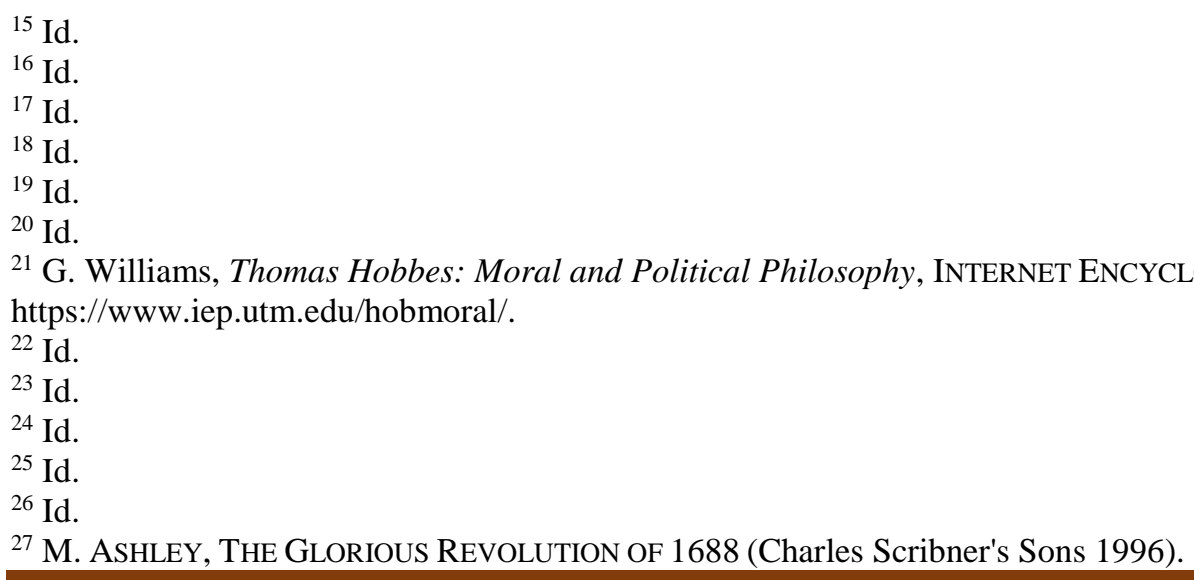




\section{The January 6, 2021 Riot, the USA FREEDOM Act of 2015, Thomas Hobbes, John Locke, and Controlling the Content of Extremist Material on the Internet}

Parliament owned property or ran businesses. ${ }^{28}{ }^{29}$ According to Locke, all human beings are born with the inalienable rights to life, liberty, and property. As far as the social contract is concerned, Locke believed that the agreement was not merely amongst the people where the monarch or dictator acted as a supervisor as espoused by Hobbes. Instead, the social contract was between the people and the sovereign. If a monarch or a dictator violates the people's inalienable rights, Locke believed that the social contract could devolve into tyranny.

For Locke, the most important of the three was not life or liberty but for the right to own property as long as the rights of others were not violated. ${ }^{30}$ Locke opined that the purpose of a government or a king was to protect the rights of the citizenry. ${ }^{31}$ Locke felt that the supreme authority of government resided in the legislature and not in the King. Parliament was solely responsible for creating courts with limited involvement from the monarchy.

\section{An Analytical Analysis of the USA FREEDOM Act}

Rather than attempting to argue whether or not Hobbes or Locke would favor the USA FREEDOM Act as a whole, it is a much more fruitful approach to analyze the positions of these two philosophers on a title-by-title basis. The reason is that it is likely that Hobbes or Locke would agree with the content of some of the titles and not others. It is conceivable that these two philosophers might agree or disagree with the Act in its entirety, but this conclusion would have more weight after conducting a title-by-title analysis and discussion.

\section{Hobbes and the USA FREEDOM Act of 2015}

Hobbes' notion of the social contract is that the citizenry contracts with each other, and the purpose of the monarch is to ensure that the citizenry honors the contract. ${ }^{32}$ Essentially, the King rules divinely to safeguard the rights of their subjects. ${ }^{33}$ For Hobbes, the monarch enacted the USA FREEDOM Act to guarantee the people's peaceful interactions, economic, political, and

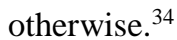

Because Hobbes was a rabid monarchist, he would probably favor Title I because the purpose of the title is to gather information on specific individuals who are possible enemies of the state. However, Hobbes would most likely disagree with the destruction of collateral data. Collateral data has intrinsic value that would preclude it from being obliterated. There are economies of effort at work here ${ }^{35}$ Hobbes would more than likely put himself in the position of the King, and it would be a waste of precious tax dollars to destroy data, only to collect it a second time when a citizen becomes a person of interest in the future. ${ }^{36}$

Hobbes would probably assume that Title II, which deals with pen registers and trap and trace devices, would be anathema. In Title II, the item to be collected had to be explicitly described. ${ }^{37}$ Hobbes would be against Title II for the same reason that he would favor Writs of Assistance. ${ }^{38}$ In 18th Century England, Writs of Assistance allowed petty government officials to search wherever the courts deemed fit. ${ }^{39}$ In a famous Pre-Revolutionary speech, James Otis, a Massachusetts colonial attorney, denounced Writs of Assistance as the "worst instrument of arbitrary power" because it placed "the liberty of every man in the hands of a petty officer." ${ }^{\prime 0}$ It was not until 100 years had passed since the publication of the Leviathan in 1650 that in Entick v. Carrington, the King's Bench rejected the idea that libelous materials could be searched for and seized by whomever wherever the Secretary of State deemed appropriate ${ }^{41}$ Lord Camden pronounced that the offense was in the government agent's reading and examining the papers. ${ }^{42}$

If Hobbes were the monarch, he would probably favor Title III because the title excludes data collected under Section 702 of the USA PATRIOT Act that a FISA court thought to be deficient. ${ }^{43}$ Hobbes would want the data to be presented to a court to be

\footnotetext{
${ }^{28}$ Hobbes, Locke, Montesquieu, and Rousseau on Government, CONSTITUTIONAL RIGHTS FoundATION, (n.d.), available at http://www.crf-usa.org/bill-of-rights-in-action/bria-20-2-c-hobbes-locke-montesquieu-and-rousseau-on-government.html.

${ }^{29}$ A. Mosley, John Locke: Political philosophy, InTERnET ENCYCLOPEDIA OF PHILOSOPHY, available at https://www.iep.utm.edu/locke-po/.

${ }^{30}$ P. J. Connolly, John Locke (1632-1704), InTERnET ENCYCLOPEDIA OF PHILOSOPHY, (n.d.), https://www.iep.utm.edu/locke/.

${ }^{31} \mathrm{Id}$.

${ }^{32}$ Hobbes, Locke, et al., supra, note 28.

${ }^{33}$ Id.

${ }^{34} \mathrm{Id}$.

${ }^{35}$ P. KRUGMAN \& R. WELls, ECONOMICS (Worth Publishers. 2017).

${ }^{36}$ Hobbes, Locke, et al., supra, note 28.

${ }^{37}$ Liu, supra, note 11.

${ }^{38}$ J. Otis, In Opposition to Writs of Assistance, (1761), available at http://www.bartleby.com/268/8/9

${ }^{39} \mathrm{Id}$.

${ }^{40} \mathrm{Id}$.

${ }^{41}$ Entick v. Carrington, 19 How. St. Tr. 1029 [1765], available at https://learninglink.oup.com/static/5c0e79ef50eddf00160f35ad/casebook_19.htm.

42 Id.

${ }^{43}$ Liu, supra, note 11.
} 


\section{The January 6, 2021 Riot, the USA FREEDOM Act of 2015, Thomas Hobbes, John Locke, and Controlling the Content of Extremist Material on the Internet}

sufficient whether to convict or acquit one of his subjects. Title IV is an intriguing title because it permits amici curiae to be appointed by a court provided that there is a novel or significant interpretation of the law. ${ }^{44}$ There is likely no reason why Hobbes would be against Title IV because he would want the public to perceive that the King's Courts were fair. This public perception would enhance the monarch's reign because the people would reject the notion that the sovereign was a tyrant. With the beheading of Charles I on January 30,1649 , the perception of being a tyrant had dire consequences. ${ }^{45}$

As argued for Title I, Hobbes would likely not approve of Title V because this title bans bulk data collection except if specific data is being collected. Title VI is related to the disclosure of the information being collected ${ }^{46}$ Hobbes would most likely be against this title because he was an advocate for the divine right of kings, and this title requires the sharing of data with Congress. ${ }^{47}$ As for Title VII, it seems that Hobbes would favor the title because it is about how to address the activities of foreign agents. If Hobbes were King, he would be keenly interested in preserving his reign and not going the way of Charles I in $1649 .{ }^{48}$ Finally, Title VIII deals with international obligations. ${ }^{49}$ Hobbes would most likely be for Title VII because traditionally, foreign affairs are within the domain of a sovereign.

In summary, when briefly analyzing Hobbes' position regarding the USA FREEDOM Act on a title-by-title basis, it is apparent that some titles would be to his liking, whereas other titles would not. It is what was expected.

\section{Locke and the USA FREEDOM Act of 2015}

For Locke, the social contract is between the citizenry and the government. ${ }^{50}$ The subjects of the King have the inalienable right to life, liberty, and property (Mosley, n.d.). For Locke, the purpose of the USA FREEDOM Act would be to warrant and protect these inalienable rights. Thus, it would be entirely appropriate for the government to pass the Act into law, provided that its purpose was to make sure that these inalienable rights are not seriously threatened. ${ }^{51}$

In 1690, John Locke published his Two Treatises. ${ }^{52}$ It was at the beginning of the reign of William and Mary of the House of Hapsburg..$^{53}$ The Glorious Revolution of 1688 had just occurred, and James II, the last of the Stuarts to sit on the English throne, was deposed. ${ }^{54}$ Title I would probably be a sweet sound to Locke's ears. Under Section 215 of the USA PATRIOT Act, the title permitted bulk data collection. ${ }^{55}{ }^{56}$ Locke would also favor Title II because it bans the wholesale collection of telephone metadata. Although Alexander Graham Bell invented telephones in the 19th Century, the 17th Century equivalent of a telephone conversation would probably be a personal conversation with a compatriot at the local English pub. ${ }^{57}$

Title III excludes any data collected under Section 702 derived from procedures thought to be deficient by a FISA court. ${ }^{58}$ Locke would support this title because he believed that the Parliament and the courts created by Parliament should dominate a nation's government. Thus, the courts, the upholders of public morality, should possess unquestionable integrity, and Locke would abhor hence insufficient data. Title IV permits amici curiae to be appointed by a FISA court under limited circumstances.$^{59}$ Locke would likely affirm Title IV for the same reason that he would favor Title III. Because Title V modifies the National Security Letter program banning bulk data collection, Locke would vote yea for this title once again.

Locke would likely approve because Title VI demands extensive disclosure requirements for FISA data collection to Congress and the public. Locke wrote that life, liberty, and property were inalienable rights, where the right to own property is of supreme importance. ${ }^{60}$ Locke would say that the Title VI statistics revealed would not violate these three rights provided that the

\footnotetext{
${ }^{44}$ Liu, supra, note 11.

${ }^{45}$ C. Carlton, Charles I: The Personal Monarch (Routledge 2nd ed. 1995).

${ }^{46}$ Liu, supra, note 11.

${ }^{47} \mathrm{Id}$.

${ }^{48}$ Carlton, supra, note 45.

${ }^{49}$ Liu, supra, note 11.

${ }^{50}$ Mosley, supra, note 29.

${ }^{51} \mathrm{Id}$.

52 JoHn LOCKe, Two TREATISES OF GOVERnMENT (Awnsham Churchill, at the Black Swan in Ave-Mary-Lane at Amen-Corner 1690).

53 Ashley, supra, note 27.

${ }^{54}$ Id.

${ }^{55}$ Fact Sheet: Section 215 of the USA PATRIOT Act, CENTER FOR STRATEGIC AND INTERNATIONAL STUDIES (2014), available at https://www.csis.org/analysis/fact-sheet-section-215-usa-patriot-act.

${ }^{56}$ Katniss Li, Section 215 of the Patriot Act Expected to Sunset in December, JOLT DiGEST (Oct. 28, 2019), available at https://jolt.law.harvard.edu/digest/section-215-of-the-patriot-act-expected-to-sunset-in-december.

${ }^{57}$ C. Gray, Reluctant Genius: The Passionate Life And InVEntive Mind of AleXander Graham Bell (Arcade 2006).

${ }^{58}$ Lui, supra, note 11.

${ }^{59}$ Id.

${ }^{60}$ Mosley, supra, note 29.
} 


\section{The January 6, 2021 Riot, the USA FREEDOM Act of 2015, Thomas Hobbes, John Locke, and Controlling the Content of Extremist Material on the Internet}

data disclosed was statistical rather than specific content data. Foreign intrigue is always a burning issue. Many individuals and foreign states desire to remove an independent government and replace it with a vassal government. For this reason, Locke would likely support both Title VII and Title VIII. Since the dawn of history, foreign affairs have been the domain of sovereign states. ${ }^{61}$ Locke would probably readily acknowledge this fact.

In summary, when briefly analyzing Locke's position regarding the USA FREEDOM Act on a title-by-title basis, it is apparent that all of the titles would be to his liking. This is good news because it demonstrates that one of the founders of democratic governments at the dawn of the Enlightenment would have favored the USA FREEDOM Act, a law consistent with the principles of democracy in this modern age.

\section{The Two Philosophical Approaches and the USA FREEDOM Act of 2015}

Initially, one could conceive that Hobbes would favor the Act. He supported an absolute monarchy, whereas Locke would be against the Act because he is considered a champion of liberty. However, when analyzing the positions of the two philosophers on a title-by-title basis, it is surprising that Hobbes would probably be against some of the Act's titles.

When analyzing Locke's potential reaction to the Act on a title-by-title basis, it is interesting to observe that he would probably be a proponent of the Act rather than an opponent. If one is a champion of liberty, one would likely believe that Locke would see the USA FREEDOM Act as an abridgment of liberty, but given his social contract ideas, he would argue that the state has a rational basis to protect its citizens. Thus, the existence of the Act could be morally justified. With the social contract argument settled, an analysis on a title-by-title basis is reasonable.

\section{CONTROLLING EXTREMISM}

In justifying the possible control and limitations of extremist material on the Internet independent of the technological feasibility, federal law is probably needed to allow the federal government to recommend and enforce such oversight. ${ }^{62}$ This is a problem of censorship and the possible abridgment of the First Amendment rights of freedom of the press. The First Amendment applies to speech that we Americans find acceptable ${ }^{63}$ and to speech that we find to be hateful or incendiary. ${ }^{64}$ The proposed law should be good in that it will not be overturned as unconstitutional. Two candidates are relevant here; namely, the Espionage Act of $1917^{65}$ and the Sedition Act of 1918. ${ }^{66}$ Both laws limit First Amendment free speech rights and are still good laws, even though they are 100 years old. Finally, the recent USA PATRIOT Act and its extension, the USA FREEDOM Act. These laws supply the basis for concluding that restricting extremist material is entirely appropriate.

In contrast, if the extremist material originates in organizations domiciled organizations in the United States, then the case law suggests that it is speech protected under the First Amendment. Some relevant cases help answer the assignment's questions, beginning with Beauharnais, ${ }^{67}$ and ending with Matal ${ }^{68}$ previously known as Lee $v$. Tam. The holdings of these cases will be briefly outlined so that a more nuanced response can be provided.

\footnotetext{
${ }^{61}$ See generally: HendRIK SPRUYT, THE SOVEREIGN StATE AND ITS COMPETITORS (Princeton University Press 1994).

${ }^{62}$ Brad Schneider, Domestic Terrorism Prevention Act (DTPA) of 2021, CONGRESSMAN BRAD SCHNEIDER (Jan. 19, 2021), available at https://schneider.house.gov/media/press-releases/domestic-terrorism-prevention-act-dtpa-2021-introduced-house. Generally, this law on domestic terrorism could be the basis of a federal law against extremeism both domestically and internationally.

${ }^{63}$ Stephen J. Ceci, \& Wendy M. Williams, Who Decides What Is Acceptable Speech on Campus? Why Restricting Free Speech Is Not the Answer, PERSPECTIVES ON PSYCHOLOGICAL SCIENCE (May 2, 2018), available at

https://journals.sagepub.com/eprint/I6zYjCxgsdtnFbmPm9FI/full.

${ }^{64}$ Chaplinsky v New Hampshire, 315 U.S. 568 (1942), available at https://supreme.justia.com/cases/federal/us/315/568/\#tabopinion-1937331. Here, fighting words are words that by speaking such words inflict injury or tend to incite an immediate breach of the peace.

${ }^{65}$ Espionage Act of 1917, DigITAL HistORY, available at https://www.digitalhistory.uh.edu/disp_textbook.cfm?smtid=3\&psid=3904.

${ }^{66}$ Christina L. Boyd, Sedition Act of 1918 (1918), ThE FIRST AMENDMENT ENCYClOPEDIA (n.d.), available at https://www.mtsu.edu/first-amendment/article/1239/sedition-act-of-1918.

${ }^{67}$ See Beauharnais v. Illinois, 343 U.S. 250 (1952), available at https://supreme.justia.com/cases/federal/us/343/250/. Here, the Supreme Court held that speech that was made by the defendant breached the U.S. libel laws, and was not protected by the First and Fourteenth Amendments.

${ }^{68}$ See Matal v. Tam, 582 U.S. ___ (2017), available at https://supreme.justia.com/cases/federal/us/582/15-1293/\#tab-opinion3749203. Here, the Court opined that the Lanham Act provisions that prohibited trademark registrations that denigrate persons, institutions, beliefs, or national symbols violated the First Amendment.
} 
The January 6, 2021 Riot, the USA FREEDOM Act of 2015, Thomas Hobbes, John Locke, and Controlling the Content of Extremist Material on the Internet

Arguments in Favor of Restricting the Extremist Material

This section outlines the Espionage Act of 1917, the Sedition Act of 1918, the USA PATRIOT Act, the USA FREEDOM Act, and the Hobbesian justification for restricting extremist material.

\section{Espionage Act of 1917}

The Espionage Act of 1917 became law on June 15, 1917, shortly after the United States entered World War I. ${ }^{69}$ The Act was passed along with the Trading with the Enemy Act of $1917^{70}$ and was based on the Defense Secrets Act of $1911 .^{71}$ The Trading with the Enemy Act made it illegal to obtain or deliver information that related to national defense to any person not entitled to receive it. The Espionage Act intended to prevent individuals from interfering with military operations and the recruitment of soldiers. The Act also prevented United States citizens from supporting the enemies of the United States during wartime. ${ }^{72}$ In Schenck v. United States, 249 US 47 (1919), the Court ruled that the Espionage Act did not violate the First Amendment. ${ }^{73}$ The constitutionality of the Espionage Act has been a legal issue ever since Schenck was decided.

\section{Sedition Act of 1918}

The Sedition Act of 1918 expanded the Espionage Act of 1917 by ensuring that speech that belittled the federal government or obstructed the sale of government bonds was illegal. ${ }^{74}$ The Sedition Act made it illegal to use disloyal, profane, or abusive language about the federal government, the United States flag, the military, or caused other people to perceive the government contemptuously. ${ }^{75}$ The Act also permitted the United States Postmaster General to refuse to deliver mail that satisfied these standards ${ }^{76}$ Some notable individuals were convicted under the Act, including the Socialist Eugene V. Debs, who received a 10year prison sentence. ${ }^{77}$ The Sedition Act was repealed in $1920 .{ }^{78}$

\section{USA PATRIOT and USA FREEDOM Acts}

In Holder, the Supreme Court dealt with the USA PATRIOT Act's prohibition against giving material support to foreign terrorist organizations. ${ }^{79}$ The Humanitarian Law Project was the first case in American jurisprudence that passed the Brandenburg test. ${ }^{80}$ The Court decided that in the USA PATRIOT Act, Congress had intended to stop aid to such groups even if the purpose of the aid was to bring about peace. The reason was that the assistance was not consistent with the Act's definition of "training" or "expert advice or assistance," "service," and "personnel." 81 The Court thought that such aid could turn a terrorist group into a legitimate organization. ${ }^{82}$ It should be noted that the USA FREEDOM Act was primarily an extension of the USA PATRIOT Act and thus would also support the restricting of extremist material.

\footnotetext{
${ }^{69}$ Harold Edgar \& Benno C. Schmidt Jr., The Espionage Statutes and the Publication of Defense Information, 73 COLUMBIA L. REV. 5, (May 1973), available at https://fas.org/sgp/library/edgar.pdf.

70 The Trading WITH THE ENEMY ACT (40 Stat. 411, enacted 6 October 1917, codified at 12 U.S.C. §§ 95a-95b and 50 U.S.C. App. $\S \S 1-44)$ restricts trade with countries that are hostile to the United States, giving power to the President to restrict trade using executive orders.

71 The Defense Secrets Act of 1911 (Pub. L. 61-470) was one of the first American that criminalized the disclosure of government secrets.

${ }^{72}$ Edgar \& Schmidt, supra, note 69.

${ }^{73}$ See Schenck v. United States, 249 U.S. 47 (1919), available at https://supreme.justia.com/cases/federal/us/249/47/. Here the Court opined that the Espionage Act of 1917 did not violate a person rights of free speech under the First Amendment when convicted under the Act.

${ }^{74}$ GeOfFrey R. Stone, Perilous Times: Free Speech in WARtime From the Sedition ACt OF 1798 to the War oN

TERRORISM (NY: W. W. Norton \& Company, 2004)

${ }^{75} \mathrm{Id}$.

${ }^{76} \mathrm{Id}$.

77 Digital History, The SEDITION ACT OF 1918, (2016), available at

http://www.digitalhistory.uh.edu/disp_textbook.cfm?smtID=3\&psid=3903.

${ }^{78} \mathrm{Id}$.

${ }^{79}$ See Holder v. Humanitarian Law Project, 561 U.S. 1 (2010), available at https://supreme.justia.com/cases/federal/us/561/1/\#tab-opinion-1963363. Here, the Court ruled against the Humanitarian Law Project (HLP). The HLP wanted to help the Kurdistan Workers' Party in Turkey and Sri Lanka's Liberation Tigers of Tamil Eelam learn how to peacefully settle conflicts.

${ }^{80}$ Eugene Volokh, The First Amendment And Related Statutes: Problems, Cases And Policy ARguments 259

(Foundation Press, 4th ed. 2011). See a discussion of Brandenburg v. Ohio below.

${ }^{81}$ See the definitions of these terms in 18 U.S. Code $\$ 2339$ B.

${ }^{82}$ Humanitarian Law Project, 561 U.S., supra, note 79.
} 
The January 6, 2021 Riot, the USA FREEDOM Act of 2015, Thomas Hobbes, John Locke, and Controlling the Content of Extremist Material on the Internet

\section{Hobbesian Justification}

In the Leviathan, Hobbs argued that a sovereign's subjects enter into a basic contract with the sovereign. ${ }^{83}$ A subject yields his or her right of self-defense and attack, while the sovereign gains the power of life and death over the sovereign's subject, a right that is ceded to the sovereign. The secession of these rights is independent of the sovereign's rules or laws. In other words, there are no subsequent conditions, either expressed or implied, that either voided the social contract or made the social contract voidable. ${ }^{84}$ Thus, in Hobbes' view, rebellion against the Espionage Act or the Sedition Act was unjustified.

\section{ARGUMENTS AGAINST RESTRICTING THE EXTREMIST MATERIAL \\ Beauharnais, Terminiello, and Brandenburg}

As was previously stated, Beauharnais, the Court held that the defendant's speech breached United States libel laws and was not protected by the First and Fourteenth Amendments. ${ }^{85}$ In Terminiello, ${ }^{86} 87$ in writing for the majority, Justice William O. Douglas wrote that speech is "protected against censorship or punishment unless shown likely to reduce a clear and present danger of a serious substantive evil that rises far above public inconvenience, annoyance, or unrest." ${ }^{\prime 8}$ In Brandenburg, the Court concluded that government could not punish speech that is inflammatory unless it is "directed to inciting or producing imminent lawless action and is likely to incite or produce such action." 8990

Village of Skokie and R.A.V.

In the Village of Skokie, in a 5-4 per curiam opinion, the Court opined that the Nazi Party's request to have a parade in Skokie, a predominately Jewish community, where the Nazi swastika was publicly displayed, did not violate the First Amendment because it was a symbolic form of free speech. ${ }^{91}{ }^{92}$ In $R A V$, the Court unanimously struck down St. Paul, Minnesota's Bias-Motivated Crime Ordinance. The Court also reversed the conviction of a teenager (a.k.a., RAV) for burning a cross on the front lawn of an African American family because it violated the teenagers' First Amendment rights of free speech. ${ }^{93}$

\section{Black, Snyder, and Matal}

In Black, the Court struck down a Virginia statute that considered the burning of a cross prima facie evidence of intent to intimidate because the state law blurred the distinction between a "threat to intimidate" and a "message of shared ideology." 94 Even so, the Court observed that if intent can be proven beyond a reasonable doubt, then the perpetrators committed a crime. ${ }^{95}$ In Snyder, the Court ruled speech on a public matter on a public street does not form the basis for liability under the intentional tort of emotional

\footnotetext{
${ }^{83}$ Leviathan Thomas Hobbes Book II Chapters 20-24, Sparknotes, (n.d.), available at http://www.sparknotes.com/philosophy/leviathan/section7/.

${ }^{84} \mathrm{Id}$.

${ }^{85}$ See Beauharnais, 343 U.S., supra, note 67.

${ }^{86}$ See Terminiello v. Chicago, 337 U.S. 1 (1949), available at https://supreme.justia.com/cases/federal/us/337/1/. Here, Arthur Terminiello, a defrocked Catholic priest repeatedly attacked Jews, communists, and liberals. In February 1946, a scuffle occurred in Chicago, and Terminiello was arrested for inciting a riot.

${ }^{87}$ Tom Head, 6 Major US Supreme Court Hate Speech Cases, THOUGHTCo., (February 19, 2018), available at https://www.thoughtco.com/hate-speech-cases-721215.

${ }^{88} \mathrm{Id}$.

${ }^{89}$ Brandenburg v. Ohio, 395 U.S. 444, 447 (1969), available at https://supreme.justia.com/cases/federal/us/395/444/. Here, Clarence Brandenburg, a leader of the Ku Klux Klan (KKK) in rural Ohio, contacted a Cincinnati television station reporter, inviting him to report on a KKK rally to be held in Hamilton County in 1964. The rally was filmed, and showed men in white robes carrying guns, burning a cross, and making speeches against "Niggers," "Jews," and anyone else who supported them.

90 Tom Head, supra, note 87.

${ }^{91}$ National Socialist Party v. Village of Skokie, 432 U.S. 43 (1977), available at https://supreme.justia.com/cases/federal/us/432/43/. In In 1977, Frank Collin who led the National Socialist Party of America (NSPA) at that time publicized that the NSPA wanted to march through Skokie, Illinois, mostly a Jewish community. Because of the unrest in the Jewish community the local government demanded that the NSPA post a public safety bond, and barred any demonstrations in Marquette Park.

92 Tom Head, supra, note 87.

${ }^{93}$ R.A.V. v. City of St. Paul, 505 U.S. 377, 380 (1992), available at https://supreme.justia.com/cases/federal/us/505/377/.

${ }^{94}$ Virginia v. Black, 538 U.S. 343 (2003), available at https://supreme.justia.com/cases/federal/us/538/343/. On May 2, 1998, and in Virginia Beach, Virginia, Richard Elliot and Jonathan O'Meara tried to burn a cross on the property Elliot's neighbor who was African American. Furthermore, on August 22, 1998 Barry Black conducted a Ku Klux Klan rally on private property. He had the consent of the owner of the property which was located in Carroll County, Virginia. Both a neighbor and the county sheriff witnessed the event, hearing racial epitaphs against African Americans. Black was arrested and charged with defying a Virginia law that made cross burnings illegal. Elliot, O’Meara, and Black were all found guilty. ${ }^{95} \mathrm{Id}$.
} 


\section{The January 6, 2021 Riot, the USA FREEDOM Act of 2015, Thomas Hobbes, John Locke, and Controlling the Content of Extremist Material on the Internet}

distress, even when the speech was offensive or outrageous. ${ }^{96}$ In Matal, the Court held that the Lanham Act provisions that prohibited trademark registrations that denigrate persons, institutions, beliefs, or national symbols violated the First Amendment. ${ }^{97}$

\section{Lockean Justification}

In the Two Treatises, Locke perceived the state of nature to be benign. ${ }^{98}$ In other words, the sovereign could impose rules and laws on the citizenry that was so onerous and burdensome that the rules and laws should be struck down, or the people should throw off the sovereign in favor of a new form of government. ${ }^{99}$ Based on the cases discussed and the fact that Thomas Jefferson and the other founding fathers were disciples of Locke, Locke would likely cheer on the Court's holdings, pointing out that the Court was championing the people's liberty. ${ }^{100}$ Even though a revolution is a distinct possibility for Locke, he would probably agree that preserving liberty through law is better than engaging in a violent revolution. ${ }^{101}$

\section{CONCLUSIONS}

On January 6, 2021, a crowd invaded the halls of Congress as people were climbing the outside walls of the building and rushing the doors. Some pundits and politicians believed that the event was an insurrection, whereas others felt a riot had happened. Hundreds of individuals have been arrested, but as of January 6, 2022, no one was charged or convicted of insurrection. The participants in the event sincerely believed that voter fraud had occurred and that Donald Trump was being denied a second term as President of the United States. Whether this belief is based on fact is an open question. It will probably be decided years from now as more information becomes publicly available. Even so, one thing is for sure. Many people in this country believe that questioning the election of Joseph Biden as President is an act of extremism. The issue is that when does the right of free assembly as guaranteed in the First Amendment break the law and descend into extremism.

It should be remembered that the prohibition against extremist material on the Internet, or otherwise, may be justified if the organization promoting the content was an organization originating in a country other than the United States. The justification would then be based on the Defense Secrets Act of 1911, the Trading with the Enemy Act of 1917, the Espionage Act of 1917, the USA PATRIOT Act of 2001, and its extension, the USA FREEDOM Act of 2015. In contrast, if the extremist material originates inside the United States from organizations based in America, then the case law discussed above indicates that extreme material would probably not be restricted because to do so would breach the First Amendment rights to free speech of the citizenry.

This essay has attempted to reconcile First Amendment rights with federal law and Supreme Court case law. It is a tricky balancing act in these days of intense political feelings and actions. Hopefully, this attempt has been successful.

\section{REFERENCES}

1) Erin Doherty, \& Oriana Gonzalez, In photos: An hour-by-hour record of the Jan. 6 Capitol riot, Axios (Jan. 6, 2022), available at https://www.axios.com/capitol-riot-january-6-anniversary-c61435e4-f4c4-4f5a-b6d1-9c463ac7eed2.html.

2) See generally, Thomas Dreisbach, Meg Anderson, \& Barbara van Woerkom, 5 Takeaways from the Capitol Riot Criminal Cases, One Year Later, NATIONAL PUBLIC RADIO (Jan. 5, 2022), available at https://www.npr.org/2022/01/05/1070199411/5-takeaways-from-the-capitol-riot-criminal-cases-one-year-later.

3) Chris Cameron, These Are the People Who Died in Connection With the Capitol Riot, THE NEW YORK TIMES (Jan. 5, 2022), available at https://www.nytimes.com/2022/01/05/us/politics/jan-6-capitol-deaths.html.

4) Jonathan Tamari, \& Julia Terruso, 'A clear and Present Danger.' Pa., N.J. Democrats Say Threats Remain a Year After the Jan. 6 Insurrection, PHILADELPHIA INQUIRER (Jan. 6, 2022), available at https://www.inquirer.com/news/pa-jan-6anniversary-casey-wild-kim-20220106.html.

5) Charlie Savage, Was the Jan. 6 Attack on the Capitol an Act of 'Terrorism'?, THE NEW YORK TIMES (Jan. 7, 2022), available at https://www.nytimes.com/2022/01/07/us/politics/jan-6-terrorism-explainer.html.

\footnotetext{
${ }^{96}$ Snyder v. Phelps, 562 U.S. 443 (2011), available at https://supreme.justia.com/cases/federal/us/562/443/. Here, Albert Snyder was a gay man whose his son, Matthew Snyder, was killed during the Iraq War while serving as a U.S. Marine. At the Matthew Snyder's funeral, Phelps and members of the Westborough Baptist Church picketed the funeral. The Court held that the speech was protected and could not be stopped because it occurred on public property.

${ }^{97}$ Matel, 582 U.S. __, 2, supra, note 68. In a unanimous decision, Justice Alito, writing for the majority, boldly proclaimed that "The disparagement clause violates the First Amendment's Free Speech Clause. Contrary to the Government's contention, trademarks are private, not government speech."

${ }^{98}$ Locke, supra, note 52.

${ }^{99} \mathrm{Id}$.

${ }^{100}$ Kenny Cota, How did John Locke influence Thomas Jefferson?, QUORA, (November 24, 2017), available at https://www.quora.com/How-did-John-Locke-influence-Thomas-Jefferson.

101 Jim Powell, John Locke: Natural Rights to Life, Liberty, and Property, FoundATION FOR ECONOMIC EDUCATION, (August 1, 1996), available at https://fee.org/articles/john-locke-natural-rights-to-life-liberty-and-property/.
} 
6) Ryan Lucas, Where the Jan. 6 insurrection investigation stands, one year later, NATIONAL PUBLIC RADIO (Jan. 6, 2022), available at https://www.npr.org/2022/01/06/1070736018/jan-6-anniversary-investigation-cases-defendantsjustice.

7) Holman W. Jenkins, Jr., Why the Jan. 6 'Big Lie' Narrative Will Fail, THE WALL STREET JOURNAL (Jan. 7, 2022), available at https://www.wsj.com/articles/the-big-lie-narrative-will-fail-mainstream-media-jan-6-journalism-2020election-capitol-riot-protest-trump-11641574341.

8) The Editorial Board, Democracy Isn't Dying, THE WALL STREET JOURNAL (Jan. 5, 2022), available at https://www.wsj.com/articles/democracy-isnt-dying-capitol-riot-jan-6-donald-trump-election-11641421265.

9) Holman W. Jenkins, Jr., supra, note 8.

10) Jody C. Liu, So what does the USA Freedom Act do anyway?, LAWFARE, (June 03, 2015), available at https://www.lawfareblog.com/so-what-does-usa-freedom-act-do-anyway,

11) Benjamin Wittes, \& Jodie Liu, So What's in the New USA Freedom Act, Anyway?, LAWFARE (May 14, 20915), available at https://www.lawfareblog.com/so-whats-new-usa-freedom-act-anyway.

12) USA Freedom Act of 2015 (Pub. L. 114-23), available at https://www.govinfo.gov/content/pkg/PLAW114publ23/html/PLAW-114publ23.htm.

13) Jody C. Liu, supra, note 11.

14) Williams, Thomas Hobbes: Moral and Political Philosophy, INTERNET ENCYCLOPEDIA OF PHILOSOPHY, (n.d.), available at https://www.iep.utm.edu/hobmoral/.

15) M. ASHLEY, THE GLORIOUS REVOLUTION OF 1688 (Charles Scribner's Sons 1996).

16) Hobbes, Locke, Montesquieu, and Rousseau on Government, CONSTITUTIONAL RIGHTS FOUNDATION, (n.d.), available at http://www.crf-usa.org/bill-of-rights-in-action/bria-20-2-c-hobbes-locke-montesquieu-and-rousseau-ongovernment.html.

17) Mosley, John Locke: Political philosophy, INTERNET ENCYCLOPEDIA OF PHILOSOPHY, available at https://www.iep.utm.edu/locke-po/.

18) P. J. Connolly, John Locke (1632-1704), INTERNET ENCYCLOPEDIA OF PHILOSOPHY, (n.d.), https://www.iep.utm.edu/locke/.

Hobbes, Locke, et al., supra, note 28.

19) P. KRUGMAN \& R. WELLS, ECONOMICS (Worth Publishers. 2017).

20) Hobbes, Locke, et al., supra, note 28.

21) Liu, supra, note 11.

22) J. Otis, In Opposition to Writs of Assistance, (1761), available at http://www.bartleby.com/268/8/9

23) Entick v. Carrington, 19 How. St. Tr. 1029 [1765], available at https://learninglink.oup.com/static/5c0e79ef50eddf00160f35ad/casebook_19.htm.

24) Liu, supra, note 11.

25) C. CARLTON, CHARLES I: THE PERSONAL MONARCH (Routledge 2nd ed. 1995).

26) Carlton, supra, note 45.

27) Mosley, supra, note 29.

28) JOHN LOCKE, TWO TREATISES OF GOVERNMENT (Awnsham Churchill, at the Black Swan in Ave-Mary-Lane at Amen-Corner 1690).

29) Ashley, supra, note 27.

30) Fact Sheet: Section 215 of the USA PATRIOT Act, CENTER FOR STRATEGIC AND INTERNATIONAL STUDIES (2014), available at https://www.csis.org/analysis/fact-sheet-section-215-usa-patriot-act.

31) Katniss Li, Section 215 of the Patriot Act Expected to Sunset in December, JOLT DIGEST (Oct. 28, 2019), available at https://jolt.law.harvard.edu/digest/section-215-of-the-patriot-act-expected-to-sunset-in-december.

32) C. GRAY, RELUCTANT GENIUS: THE PASSIONATE LIFE AND INVENTIVE MIND OF ALEXANDER GRAHAM BELL (Arcade 2006).

33) Mosley, supra, note 29.

34) See generally: HENDRIK SPRUYT, THE SOVEREIGN STATE AND ITS COMPETITORS (Princeton University Press 1994).

35) Brad Schneider, Domestic Terrorism Prevention Act (DTPA) of 2021, CONGRESSMAN BRAD SCHNEIDER (Jan. 19, 2021), available at https://schneider.house.gov/media/press-releases/domestic-terrorism-prevention-act-dtpa-2021introduced-house. Generally, this law on domestic terrorism could be the basis of a federal law against extremeism both domestically and internationally. 
36) Stephen J. Ceci, \& Wendy M. Williams, Who Decides What Is Acceptable Speech on Campus? Why Restricting Free Speech Is Not the Answer, PERSPECTIVES ON PSYCHOLOGICAL SCIENCE (May 2, 2018), available at https://journals.sagepub.com/eprint/I6zYjCxgsdtnFbmPm9FI/full.

37) Chaplinsky v New Hampshire, 315 U.S. 568 (1942), available at https://supreme.justia.com/cases/federal/us/315/568/\#tabopinion-1937331. Here, fighting words are words that by speaking such words inflict injury or tend to incite an immediate breach of the peace.

38) Espionage Act of 1917, DIGITAL HISTORY, available at https://www.digitalhistory.uh.edu/disp_textbook.cfm?smtid=3\&psid=3904.

39) Christina L. Boyd, Sedition Act of 1918 (1918), THE FIRST AMENDMENT ENCYCLOPEDIA (n.d.), available at https://www.mtsu.edu/first-amendment/article/1239/sedition-act-of-1918.

40) See Beauharnais v. Illinois, 343 U.S. 250 (1952), available at https://supreme.justia.com/cases/federal/us/343/250/. Here, the Supreme Court held that speech that was made by the defendant breached the U.S. libel laws, and was not protected by the First and Fourteenth Amendments.

41) See Matal v. Tam, 582 U.S. _ (2017), available at https://supreme.justia.com/cases/federal/us/582/15-1293/\#tabopinion-3749203. Here, the Court opined that the Lanham Act provisions that prohibited trademark registrations that denigrate persons, institutions, beliefs, or national symbols violated the First Amendment.

42) Harold Edgar \& Benno C. Schmidt Jr., The Espionage Statutes and the Publication of Defense Information, 73 COLUMBIA L. REV. 5, (May 1973), available at https://fas.org/sgp/library/edgar.pdf.

43) THE TRADING WITH THE ENEMY ACT (40 Stat. 411, enacted 6 October 1917, codified at 12 U.S.C. §§ 95a-95b and 50 U.S.C. App. §§ 1-44) restricts trade with countries that are hostile to the United States, giving power to the President to restrict trade using executive orders.

44) The Defense Secrets Act of 1911 (Pub. L. 61-470) was one of the first American that criminalized the disclosure of government secrets.

45) Edgar \& Schmidt, supra, note 69.

46) See Schenck v. United States, 249 U.S. 47 (1919), available at https://supreme.justia.com/cases/federal/us/249/47/. Here the Court opined that the Espionage Act of 1917 did not violate a person rights of free speech under the First Amendment when convicted under the Act.

47) GEOFFREY R. STONE, PERILOUS TIMES: FREE SPEECH IN WARTIME FROM THE SEDITION ACT OF 1798 TO THE WAR ON TERRORISM (NY: W. W. Norton \& Company, 2004)

48) Digital History, THE SEDITION ACT OF 1918, (2016), available at http://www.digitalhistory.uh.edu/disp_textbook.cfm?smtID=3\&psid=3903.

49) See Holder v. Humanitarian Law Project, 561 U.S. 1 (2010), available at https://supreme.justia.com/cases/federal/us/561/1/\#tab-opinion-1963363. Here, the Court ruled against the Humanitarian Law Project (HLP). The HLP wanted to help the Kurdistan Workers' Party in Turkey and Sri Lanka's Liberation Tigers of Tamil Eelam learn how to peacefully settle conflicts.

50) EUGENE VOLOKH, THE FIRST AMENDMENT AND RELATED STATUTES: PROBLEMS, CASES AND POLICY ARGUMENTS 259 (Foundation Press, 4th ed. 2011). See a discussion of Brandenburg v. Ohio below.

51) See the definitions of these terms in 18 U.S. Code $\S 2339 B$.

52) Humanitarian Law Project, 561 U.S., supra, note 79.

53) Leviathan Thomas Hobbes Book II Chapters 20-24, Sparknotes, (n.d.), available at http://www.sparknotes.com/philosophy/leviathan/section7/.

54) See Beauharnais, 343 U.S., supra, note 67.

55) See Terminiello v. Chicago, 337 U.S. 1 (1949), available at https://supreme.justia.com/cases/federal/us/337/1/. Here, Arthur Terminiello, a defrocked Catholic priest repeatedly attacked Jews, communists, and liberals. In February 1946, a scuffle occurred in Chicago, and Terminiello was arrested for inciting a riot.

56) Tom Head, 6 Major US Supreme Court Hate Speech Cases, THOUGHTCO., (February 19, 2018), available at https://www.thoughtco.com/hate-speech-cases-721215.

57) Brandenburg v. Ohio, 395 U.S. 444, 447 (1969), available at https://supreme.justia.com/cases/federal/us/395/444/. Here, Clarence Brandenburg, a leader of the Ku Klux Klan (KKK) in rural Ohio, contacted a Cincinnati television station reporter, inviting him to report on a KKK rally to be held in Hamilton County in 1964. The rally was filmed, and showed men in white robes carrying guns, burning a cross, and making speeches against "Niggers," "Jews," and anyone else who supported them.

58) Tom Head, supra, note 87. 
59) National Socialist Party v. Village of Skokie, 432 U.S. 43 (1977), available at https://supreme.justia.com/cases/federal/us/432/43/. In In 1977, Frank Collin who led the National Socialist Party of America (NSPA) at that time publicized that the NSPA wanted to march through Skokie, Illinois, mostly a Jewish community. Because of the unrest in the Jewish community the local government demanded that the NSPA post a public safety bond, and barred any demonstrations in Marquette Park.

60) Tom Head, supra, note 87.

61) R.A.V. v. City of St. Paul, 505 U.S. 377, 380 (1992), available at https://supreme.justia.com/cases/federal/us/505/377/.

62) Virginia v. Black, 538 U.S. 343 (2003), available at https://supreme.justia.com/cases/federal/us/538/343/. On May 2, 1998, and in Virginia Beach, Virginia, Richard Elliot and Jonathan O'Meara tried to burn a cross on the property Elliot's neighbor who was African American. Furthermore, on August 22, 1998 Barry Black conducted a Ku Klux Klan rally on private property. He had the consent of the owner of the property which was located in Carroll County, Virginia. Both a neighbor and the county sheriff witnessed the event, hearing racial epitaphs against African Americans. Black was arrested and charged with defying a Virginia law that made cross burnings illegal. Elliot, O'Meara, and Black were all found guilty.

63) Snyder v. Phelps, 562 U.S. 443 (2011), available at https://supreme.justia.com/cases/federal/us/562/443/. Here, Albert Snyder was a gay man whose his son, Matthew Snyder, was killed during the Iraq War while serving as a U.S. Marine. At the Matthew Snyder's funeral, Phelps and members of the Westborough Baptist Church picketed the funeral. The Court held that the speech was protected and could not be stopped because it occurred on public property.

64) Matel, 582 U.S. __, 2, supra, note 68. In a unanimous decision, Justice Alito, writing for the majority, boldly proclaimed that "The disparagement clause violates the First Amendment's Free Speech Clause. Contrary to the Government's contention, trademarks are private, not government speech."

65) Locke, supra, note 52.

66) Kenny Cota, How did John Locke influence Thomas Jefferson?, QUORA, (November 24, 2017), available at https://www.quora.com/How-did-John-Locke-influence-Thomas-Jefferson.

67) Jim Powell, John Locke: Natural Rights to Life, Liberty, and Property, FOUNDATION FOR ECONOMIC EDUCATION, (August 1, 1996), available at https://fee.org/articles/john-locke-natural-rights-to-life-liberty-and-property/. 